\title{
Health Communication Issues of the People in Street Situation during Pandemic Covid-19
}

\author{
Erwin Rasyid ${ }^{1}$, Ade Putranto Prasetyo Wijiharto Tunggali ${ }^{2}$, Hari Akbar Sugiantoro ${ }^{3}$ \\ \{erwin.rasyid@unisayogya.ac.id ${ }^{1}$ \} \\ Communication Department, Universitas Aisyiyah Yogyakarta, Indonesia ${ }^{1,2,3}$
}

\begin{abstract}
People living on the streets is a phenomenon that occurs in a number of cities throughout Indonesia. Yogyakarta, like other cities, faces the same issue. People on the streets face an even greater challenge during pandemics. This raises additional concerns, including the threat of homelessness, poverty, and insufficient health care access. The purpose of this study is to examine the health communication issues confronting people on the street during the Covid-19 pandemic. This study employs a qualitative approach with a phenomenological orientation. Age growth has an effect on and affects the welfare of people living on the street. Individuals living on the street face new challenges such as health concerns, family conflicts, sexually transmitted infections (STIs), and unplanned pregnancy (KTD). The situation in Covid-19 has resulted in street people having difficulty accessing health care. The actors involved must develop interpersonal trust with the people they encounter on the street. To gain the trust of strangers on the street, informal communication can be used. Particularly on issues concerning health communication.
\end{abstract}

Keywords: People in the street situation, pandemic covid-19, health communication issues

\section{Introduction}

Street children are a current occurrence in a number of cities throughout Indonesia. Numerous factors contribute to children's preference for street life. As with other cities, Yogyakarta faces the same issue of street children. One of the most difficult aspects of achieving children's rights, particularly on the streets, is that the majority of them still lack a distinct identity [1]. Children living on the streets are not limited to nomads or the homeless. However, street children are also included in disadvantaged communities located in the suburbs of urban villages.

The streets are synonymous with deplorable conditions and hazardous areas. Children on the street are classified as being in a bad situation [2]. Numerous factors contribute to children's involvement in street situations, including an unfavorable home climate, poverty, the allure of freedom, drugs, and uncontrollable space for adults [3]. This is also what motivates some Yogyakarta children to choose the street as their alternative living space. Children's problems in street situations remain the same, namely education, economics, and health. However, funding for children living on the streets is primarily directed toward education and economic development. The health component is frequently overlooked by the stakeholders.

The issue becomes more complicated because street children are socially connected to a variety of different elements, including their parents, the Social Service, the Police, nongovernmental organizations (NGOs), the Open Houses, the Chief Coordinator, and peers who 
are not only children but also adults. This ambiguity clouds the policy regarding street children. [4]. The complexity of poverty necessitates that individual take an inventive step to assist the government in alleviating poverty. Social entrepreneurship is one strategy for addressing this issue [5].

Children as a young generation, potential and future generations with unique ambitions and characteristics must be protected from all forms of inhumane treatment that result in human rights violations, according to the act 35/2014. Children's rights are an integral part of the human rights that pertain to the State's position, and as such, each nation should protect, fulfill, and respect children's rights [6].

According to the National Socio-Economic Survey (SUSENAS), there are approximately 4.8 million street children in the United States. Two years later, this percentage increased to 8.4 percent, bringing the total number of street children to 9.1 million. The Yogyakarta Special Area has a total of 2076 street children (BPSRI 2012). This number continues to rise year after year. In the Yogyakarta Special Region (DIY), a critical issue for street children is a lack of personal and social skills [4].

The Yogyakarta City Government has announced a series of measures aimed at reducing children's height in street situations. Apart from conducting raids and social rehabilitation, the Government of the Yogyakarta Special Region issued Regional Regulation No. 1 of 2014 on the Treatment of Homeless and Beggars for Control. However, some parties believe that these laws fall short of resolving and protecting children in street situations. The Yogyakarta City Government's strategy of excluding children from roads through special education programs that combine informal and non-formal education is also not ideal [7].

The majority of children living on the streets rely on their daily earnings. Economic concerns are one of the most impacted. The majority of street children rely on their daily earnings. Street children face an even greater threat in the event of a pandemic. This raises additional concerns, such as the threat of homelessness, hunger, and a lack of means of subsistence.

According to the findings of a survey conducted by the Yogyakarta Legal Aid Institute (LBH), the majority of street children have shifted from begging or selling crackers to street singers as a result of the homework (WFH) policy and social distancing [8]. Additionally, children living on the streets are becoming increasingly depressed as a result of Yogyakarta's implementation of curfews during the Covid-19 pandemic. This situation has gotten worse as prices for basic commodities such as sugar, eggs, cooking oil, and rice have increased. Children living on the streets have few avenues for requesting assistance in resolving their problems during the Covid-19 Pandemic. The purpose of this study is to examine the health communication challenges encountered by people on the street during the Covid-19 Pandemic.

\section{Method}

This research uses a qualitative descriptive method with a phenomenological approach. The phenomenological approach in the study of communication means enabling anything to be as authentic as possible without placing categories of researchers on the subject under investigation. The topics studied were the population of street people who were accompanied by the Harapan Fian Association. The Harapan Fian Association (HF) is an organization concerned with promoting human rights in street situations. This study's data collection 
approach was applied in two ways by in-depth interviewing and observation techniques. An interpretative phenomenological analysis is the data analysis approach used (IPA).

There are three steps in the qualitative research process. The first stage is orientation; at this stage, the researcher will find the phenomenon studied. Second, the reduction stage is when the researcher chooses exciting and essential data to categorize. The third stage is the selection stage; at this stage, the data has been classified, then analyzed, and presented in more detail. The IPA stages consist of Reading and Reading, Initial Notes, Looking for Connections Across Emergent Theme, Moving Next Cases, and Searching for Patterns Across Cases.

\section{Results and Discussions}

The study of health communication has shifted away from an objective model toward a subjective one. This condition is exacerbated by the complexities of people's lives, as they become increasingly aware that understanding the opposing viewpoint on a subject is critical for effective, empathic communication [9]. Subjectively, the study aims to see if people's impressions of street conditions during the Covid-19 Pandemic have operated. Data on people's health contact problems in street situations during the Covid-19 Pandemic have been extracted from this personal experience. Based on the supported data from Harapan Fian, the issues faced by people in street situations before the Covid-19 Pandemic are as follows Figure 1.
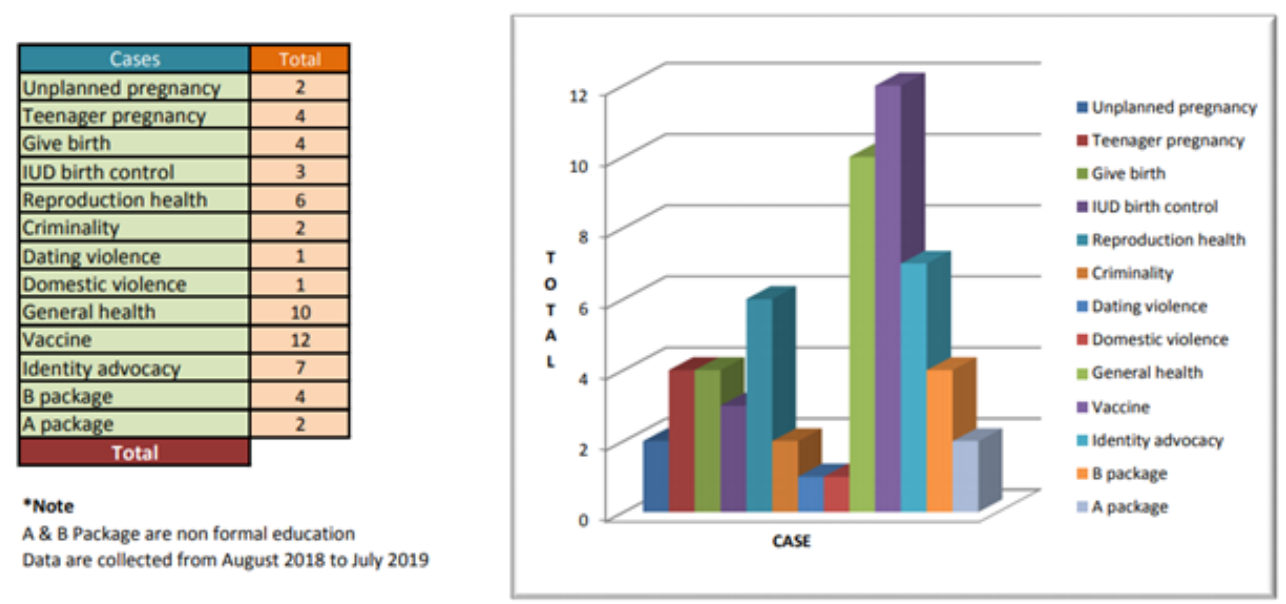

Fig. 1. Case Handled by Harapan Fian in 2018-2019 (Source: Perkumpulan Harapan Fian)

The problem of health contact for people in street situations is affected by several factors, including age, the social atmosphere, and the family. During the Covid-19 Pandemic, people in street circumstances were among the most vulnerable and at risk. The following a Figure 1, illustrating the health contact problems faced by people in street circumstances during the Covid-19 Pandemic as follow Figure 2. 


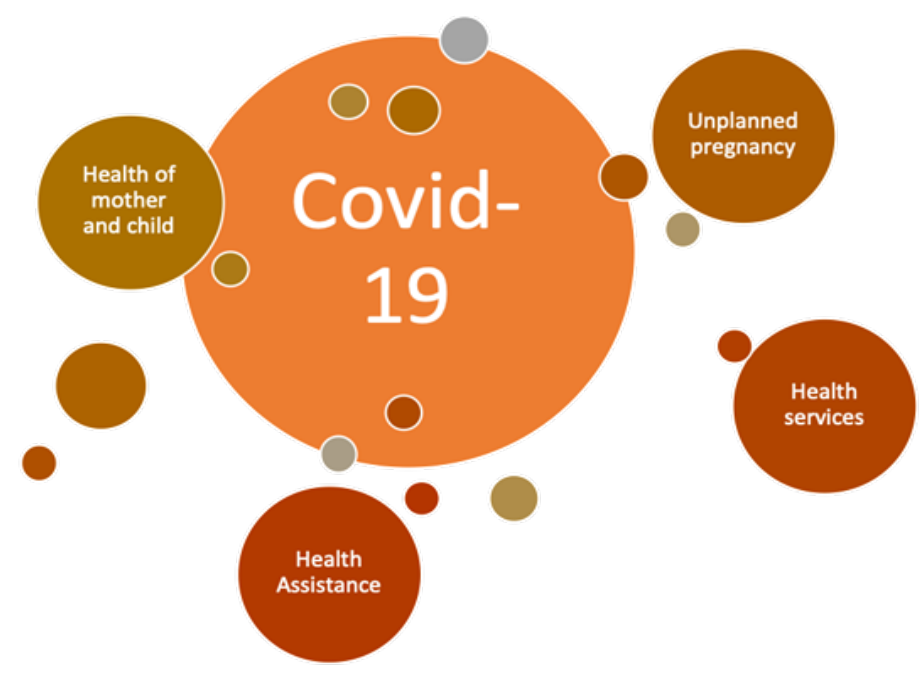

Fig. 2. Health Communication Issues of the People in Street Situation During Pandemic Covid-19

Age growth defines and affects health problems for people living in street conditions. People in the street face several new health issues when they enter the adolescent phase. Among the reproductive health issues are family conflict and sexually transmitted infections (STIs) in unplanned pregnancy (KTD). During a pandemic, women and children are the most vulnerable segments of the street population.

The Covid-19 pandemic resulted in an increase in the unplanned birth rate in the community of people in street situations. This study found two adolescent girls who experienced an unplanned pregnancy (KTD) and a baby's birth from three women who experienced KTD. Besides, there were also two cases of malnourished babies and ten babies who were susceptible to disease because they had not received immunization services. Women in street situations also have difficulty accessing contraceptive services due to limited access to health services such as Puskesmas. The Covid-19 pandemic makes it difficult for children and women to get proper and comprehensive health services in street situations. Many reproductive health services are not running because health care currently focuses on dealing with the pandemic.

People in street situations who are female have a more nuanced burden on reproductive health issues. Maternal and Child Health Problems (KIA) are also crucial issues facing people in street circumstances. During the Covid-19 Pandemic, they were forced to monitor the healthy development of their children independently. They will need to track the nutritional status of their children to prevent stunting ability. Children living on the streets have few opportunities to seek assistance in resolving their health problems. The study also found that there were not enough health centers and facilities to offer health care to people living in street circumstances. This is due to the small number of health units that can promote and provide primary health care for disadvantaged groups, such as those on the street.

Government protection agencies must approach street children's protection from a street child's perspective, enabling them to leave the streets [10]. But, Assistance to street children focuses more on education and economic development [11]. As a result of the effects of the Covid-19 Pandemic, people's activities in street situations have been restricted, along with the introduction of the Large-Scale Social Restrictions (PSBB) program. This affects their daily economic activities. As a result, there are few people in the street situation. The Covid-19 
pandemic has exacerbated people's condition in street circumstances due to the difficulties of accessing health care facilities. People in street circumstances have trouble accessing free health facilities due to a lack of identification. So regular check-ups are challenging to do where this disease can cause different kinds of other health issues. The current assistance focuses only on children in street conditions that are under the age of 17. Children in adolescent situations have received little additional support from relevant stakeholders. In reality, adolescents who live on the streets face more complicated health issues.

\section{Conclusion}

The health aspects of people in street situations need to be of grave concern to the relevant stakeholders responsible for coping with this problem. The Covid-19 pandemic has exacerbated people's condition in street circumstances due to the difficulties of accessing health care facilities. People living in street conditions, as a disadvantaged community, need assistance in obtaining appropriate health services. Not only did it apply to the health issues discussed earlier, but it also pointed to how to avoid such health conditions from occurring. Individuals living on the street do not have many options for coping with the person they are confronted withparticularly when it comes to issues of wellbeing. Therefore, qualified health professionals who explicitly provide health services to community people in street situations, particularly during the Covid-19 Pandemic, are required.

\section{Acknowledgments}

The Ministry of Research and Higher Education (Kemenristek) funded this research through the 2019/2020 Beginner Lecturer Research (PDP) grant scheme. Additionally, Lembaga Penelitian dan Pemberdayaan Masyarakat (LPPM) Universitas Aisyiyah Yogyakarta supported this research.

\section{References}

[1] A. Pas and B. Kartowagiran, "Evaluasi Implementasi Perda Nomor 6 Tahun 2011 Tentang Perlindungan Anak Yang Hidup di Jalan,” J. Pembang. Pendidik. Fondasi dan Apl., vol. 6, no. 1, pp. 36-49, 2018.

[2] D. Aufseeser, "Towards a relational understanding of child poverty: Care and adverse inclusion among street-affiliated children in Peru," Geoforum, vol. 114, no. May, pp. 10-18, 2020, doi: 10.1016/j.geoforum.2020.05.016.

[3] J. P. Joanou, "Tu sabes que somos de calle: The Role of Thirdspace in the Construction of a Street Child Identity," J. Contemp. Ethnogr., vol. 43, no. 5, pp. 601-623, 2014, doi: $10.1177 / 0891241613514445$.

[4] I. Kertati, "Deformasi Kebijakan Penangan Anak Jalanan Kota Semarang," J. Riptek, vol. 12, no. 1, pp. 129-142, 2018.

[5] M. Saputra, "Pemberdayaan Warga Negara Dan Kewirausahaan Sosial: Pemutusan Mata Rantai Anak Jalanan,” J. Ilm. Pendidik. Pancasila dan Kewarganegaraan, vol. 3, no. 2, p. 144, 2018, doi: 10.17977/um019v3i2p144-148. 
[6] B. Hasanah and L. D. Putri, "Efektivitas Program Penanggulangan Anak Jalanan Berbasis Community Development di Kota Serang (Studi Pada Program Rumah Singgah),” Publik (Jurnal Ilmu Adm., vol. 7, no. 2, p. 81, 2019, doi: 10.31314/pjia.7.2.81-93.2018.

[7] S. Syahrul and A. Wardana, "Analisis kebijakan pendidikan untuk anak jalanan di Kota Yogyakarta," Harmon. Sos. J. Pendidik. IPS, vol. 4, no. 2, pp. 117-130, 2018, doi: 10.21831/hsjpi.v4i2.10388.

[8] Agus Fujiyanto et al., "Mandiri di Tengah Pandemi: Laporan Survey Dampak Covid-19 terhadap 11 Organisasi Paralegal Komunitas," Yogyakarta, 2020. [Online]. Available: https://drive.google.com/file/d/1f7w0QnN3yfmxjjDE5qnRkb0xJbAQO-aZ/view?usp=sharing.

[9] D. Mulyana et al., Komunikasi Kesehatan: Pemikiran dan Penelitian. Bandung: Remaja Rosdakarya, 2018.

[10] A. Bajari and E. Kuswarno, "Violent language in the environment of street children singer-beggars," Heliyon, vol. 6, no. 8, p. e04664, 2020, doi: 10.1016/j.heliyon.2020.e04664.

[11] E. Rasyid, A. Putranto, P. Wijiharto, and H. Akbar, "Trust Issues in Health Communication of Children in Street Situation Masalah Kepercayaan dalam Komunikasi Kesehatan Anak di Situasi Jalanan,” vol. 6, no. 1, pp. 110-121, 2021. 